\title{
PCR-based detection of Plasmodium falciparum in saliva using mitochondrial cox3 and varATS primers
}

Yukie M. Lloyd ${ }^{1 *}$ D, Livo F. Esemu², Jovikka Antallan, Bradley Thomas', Samuel Tassi Yunga ${ }^{1,6}$, Bekindaka Obase ${ }^{3}$, Nana Christine', Rose G. F. Leke ${ }^{2}$, Richard Culleton ${ }^{4,5}$, Kenji Obadiah Mfuh', Vivek R. Nerurkar' and Diane Wallace Taylor ${ }^{1 *}$

\begin{abstract}
Background: Sampling of saliva for diagnosing Plasmodium falciparum infections is a safe, non-invasive alternative to sampling of blood. However, the use of saliva presents a challenge because lower concentrations of parasite DNA are present in saliva compared to peripheral blood. Therefore, a sensitive method is needed for detection of parasite DNA in saliva. This study utilized two recently reported "ultra-sensitive" PCR assays based on detection of the $P$. falciparum mitochondrial cox3 gene and the multi-copy nuclear varATS gene. The ultra-sensitive assays have an advantage over standard $18 \mathrm{~S}$ rRNA gene-based PCR assay as they target genes with higher copy numbers per parasite genome. Stored saliva DNA samples from 60 Cameroonian individuals with infections previously confirmed by $18 \mathrm{~S}$ rRNA gene PCR in peripheral blood were tested with assays targeting the cox3 and varATS genes.

Results: Overall, the standard 18S rRNA gene-based PCR assay detected P. falciparum DNA in 62\% of the stored saliva DNA samples, whereas 77 and $68 \%$ of the samples were positive with assays that target the cox3 and varATS genes, respectively. Interestingly, the ultra-sensitive assays detected more $P$. falciparum infections in stored saliva samples than were originally detected by thick-film microscopy $(41 / 60=68 \%)$. When stratified by number of parasites in the blood, the cox3 assay successfully detected more than 90\% of infections using saliva when individuals had $>1000$ parasites $/ \mu$ l of peripheral blood, but sensitivity was reduced at submicroscopic parasitemia levels. Bands on electrophoresis gels were distinct for the cox3 assay, whereas faint or non-specific bands were sometimes observed for varATS and 18S rRNA that made interpretation of results difficult. Assays could be completed in 3.5 and $3 \mathrm{~h}$ for the cox3 and varATS assays, respectively, whereas the $18 \mathrm{~S}$ rRNA gene assays required at least $7 \mathrm{~h}$.

Conclusions: This study demonstrates that a PCR assay targeting the cox3 gene detected $P$. falciparum DNA in more saliva samples than primers for the $18 \mathrm{~S}$ rRNA gene. Non-invasive collection of saliva in combination with the proposed cox3 primer-based PCR assay could potentially enhance routine testing of $P$. falciparum during disease surveillance, monitoring, and evaluation of interventions for malaria elimination.
\end{abstract}

Keywords: Malaria diagnosis, Saliva-based assays, Detection, Cameroon, Plasmodium falciparum, Malaria surveillance, $18 \mathrm{~S}$ rRNA, varATS, cox3, Mitochondrial genome

\footnotetext{
* Correspondence: yukiem@hawaii.edu; dwtaylor@hawaii.edu

'Department of Tropical Medicine, Medical Microbiology and Pharmacology,

John A. Burns School of Medicine, University of Hawaii at Manoa, Honolulu,

HI 96813, USA

Full list of author information is available at the end of the article
}

(c) The Author(s). 2018 Open Access This article is distributed under the terms of the Creative Commons Attribution 4.0 International License (http://creativecommons.org/licenses/by/4.0/), which permits unrestricted use, distribution, and reproduction in any medium, provided you give appropriate credit to the original author(s) and the source, provide a link to the Creative Commons license, and indicate if changes were made. The Creative Commons Public Domain Dedication waiver (http://creativecommons.org/publicdomain/zero/1.0/) applies to the data made available in this article, unless otherwise stated. 


\section{Background}

Early and accurate diagnosis of Plasmodium falciparum $(P f)$ infections is crucial for treatment and monitoring of malaria transmission. Thick-film microscopy (TFM) has traditionally been the gold standard for the identification of Pf from peripheral blood. A trained microscopist can typically detect 50-100 parasites/ $\mu$ l of blood in Giemsa's solution-stained blood smear [1], but individuals with fewer parasites may be erroneously diagnosed as parasite-free. Although people with submicroscopic infections are usually not ill, they are capable of transmitting sexual-stage parasites to mosquitoes [2]. Submicroscopic infections can be detected by highly sensitive molecular assays, such as nested PCR (nPCR) and loop-mediated isothermal amplification (LAMP) [3]. With the use of nPCR and LAMP, the limit of detection is estimated to be $0.1-10$ parasites/ $\mu \mathrm{l}$ of blood and can be lower still with qRT-PCR [4]. Current diagnostic and molecular methods have an inherent problem; they require collection of peripheral blood. Routine blood collection methods are invasive procedures that are painful to patients, require trained phlebotomists, and involve the use of needles or lancets. Improper handling of sharps exposes healthcare workers and the patient to blood-borne pathogens, while disposal of used sharps is hazardous for waste management in malaria-endemic countries [5]. Repetitive sampling of blood from the same person, e.g., in mass studies monitoring malaria elimination, often results in low compliance.

Non-blood samples, e.g., saliva and urine, can serve as non-invasive and safe alternatives to blood samples. Plasmodium DNA has been detected in saliva and urine [6], however, at 600 and 2500 times lower levels, respectively [7], than those present in peripheral blood. Despite the reduced amount of parasite DNA in saliva, quantitative studies show a positive correlation between parasite numbers detected in peripheral blood by microscopy and parasite DNA in saliva $[7,8]$, which supports the use of saliva as an alternative for blood.

The traditional molecular assay used for $P f$ detection targets a specific region in the $18 \mathrm{~S}$ ribosomal RNA (18S rRNA) gene [9] that has 4-8 copies per Pf genome. Recently, primers to multi-copy gene targets have been reported to have improved sensitivity. One is the mitochondrial cytochrome c oxidase III (cox3) gene, with 20 to 150 copies per Pf genome. Because cox3 is a mitochondrial gene, it is less likely to undergo immune pressure and genetic variation. The other gene is the var gene acidic terminal sequence (varATS), $\sim 59$ copies/Pf genome [4, 10, 11]. Cunha et al. reported detection of submicroscopic infections in the blood by qPCR using varATS primers that were missed by $18 \mathrm{~S}$ rRNA gene primers. Since conventional instrumentation of qPCR can be difficult to maintain in resource poor countries where malaria is transmitted, a conventional PCR method might be more useful.

A recent study was conducted in Cameroon using $18 \mathrm{~S}$ rRNA gene PCR to detect Pf DNA in the saliva of 222 fever patients. The study was able to detect $P f$ DNA in saliva in 95\% [95\% CI 85-99] of 53 subjects who were peripheral blood smear positive by microscopy and $82 \%$ [95\% CI 72-90] of 78 blood samples positive by PCR [8]. The current study hypothesized that the use of these "ultra-sensitive" primers to detect malaria DNA in saliva would increase the number of $P f$ cases detected compared to the use of the traditional $18 \mathrm{~S}$ rRNA gene PCR.

\section{Methods}

\section{Sample selection}

Paired blood and saliva samples were collected in 2015 from febrile patients in Cameroon as previously described [8]. Saliva were collected using the OMNIgene ${ }^{\circ} \mathrm{ORAL}$ (OM-501) kits (Genotek, Ottawa, Canada). In the original study, DNA was isolated from whole blood and saliva using a DNA purification kit (Macherey Nagel, Duren, Germany) and stored at $-20{ }^{\circ} \mathrm{C}$ until used. In the current study, 60 stored archival saliva DNA samples were available from subjects who originally tested peripheral blood positive by PCR using $18 \mathrm{~S}$ rRNA gene PCR. As a positive control, DNA isolated from laboratory-cultured $P f$ of the 3D7 strain was serially diluted five-folds from 3.74 to $4 \times 10^{-7} \mathrm{ng} / \mu \mathrm{l}$ of parasite DNA. Negative controls were saliva samples collected from three U.S. individuals who were malaria naïve, and a non-template control with nuclease-free PCR-grade water was substituted for the DNA template.

\section{Nested PCR amplification of 18S rRNA}

In the original study, the following protocol was used. One PCR reaction consisted of $12.5 \mu \mathrm{l}$ of $2 \mathrm{x}$ Go Taq Green (Promega, Madison, USA), $1 \mu$ l each of $10 \mu \mathrm{M}$ forward and reverse primers (IDT, IA, USA), $5.5 \mu \mathrm{l}$ of nuclease-free water, and $5 \mu \mathrm{l}$ of DNA template, with a total of $25 \mu \mathrm{l}$. The standard protocols for the cycling conditions were followed [9]. For the initial amplification targeting the $18 \mathrm{~S}$ rRNA gene, forward and reverse primers, rPLU5 (5'-CCTGTTGTTGCCTTAAACT TC-3') and rPLU6 (5'-TTAAAATTGTTGCAGTTAA AACG-3') were used. Five microliters of the amplified product was used for the second round of amplification with forward and reverse primers, rFAL-1 (5'-TTAA ACTGGTTTGGGAAAACCAAATATATT-3') and rFA L-2 (5' -ACACAATGAACTCAATCATGACTACCCGT C) [9]. The expected product size was 205 base pairs (bp). In the current study, the above protocol was employed, except $5 \mu \mathrm{l}$ of DNA was used (instead of $2 \mu \mathrm{l})$ to allow for direct comparison among the primers. 


\section{Nested PCR amplification of mitochondrial cytochrome C oxidase III (cox3)}

For the initial amplification targeting cox3, forward and reverse primers, MtU.F (5' -CTCGCCATTTGATAGCGGT TAACC-3') and MtU.R (5' -CCTGTTATCCCCGGCGAAC CTTC-3') were used with standard protocols for the cycling conditions [10]. Five microliters of the amplified product, diluted at 1:50, was used for the second amplification with forward and reverse primers MtNst_falF (5'-GAACACAAT TGTCTATTCGTACAATTATTC-3') and MtNst_falR (5'-CTTCTACCGAATGGTTTATAAATTCTTTC-3'). The expected product size was $201 \mathrm{bp}$.

\section{PCR amplification of varATS}

For the amplification targeting varATS, forward varATS primer (5'-CCCATACACAACCAAYTGGA-3') and reverse varATS primer (5'-TTCGCACATATCTCTATGTCTATC T-3') were used with standard protocols for the cycling conditions [4]. The expected product size was $65 \mathrm{bp}$.

\section{Gel electrophoresis}

Ten microliters of the PCR products were run on a 1.5\% agarose gel (Sigma, Fisher, USA) stained with ethidium bromide (Sigma-Aldrich, USA) for $45 \mathrm{~min}$ at $100 \mathrm{~V}$. Products were visualized under a UV lamp. A 100-bp ladder (exACTGene Ladder, Fisher) was used as a reference. The presence of a band at the expected size for each primer set was determined positive.

\section{Statistical data analysis}

Data analyses were conducted using Microsoft Excel and Prism version 7.04 (Graph Pad Software Inc.). The 95\% confidence interval was calculated using the modified Wald method.

\section{Results}

Comparison of the limit of detection of the three primers DNA isolated from $P$. falciparum cultured in vitro that contained from 3.74 to $4 \times 10^{-7} \mathrm{ng} / \mu \mathrm{l}$ of parasite DNA was serially diluted fivefold and used as the positive control in the assays. The lower limit of detection (i.e., presence of a band following gel electrophoresis) using the $18 \mathrm{~S}$ rRNA primers reached $1 \times 10^{-5} \mathrm{ng} / \mu \mathrm{l}$; cox3 primer was $4 \times 10^{-7} \mathrm{ng} / \mu \mathrm{l}$; and varATS primer was $2 \times$ $10^{-6} \mathrm{ng} / \mu \mathrm{l}$. It is important to point out that both the $18 \mathrm{~S}$ rRNA and cox3 assays are nested PCRs, where $5 \mu \mathrm{l}$ of the nest 1 produce is used in nest 2 of the $18 \mathrm{~S}$ rRNA assay, but $5 \mu \mathrm{l}$ of a 1:50 dilution of the nest 1 was used in nest 2 of the $\operatorname{cox} 3$ assay. The varATS assay was a single-step PCR assay. Thus, the cox3 assay was the most sensitive assay, with the varATS having a lower limit of detection similar to that of the nest-PCR $18 \mathrm{~S}$ rRNA method.
Detection of Pf DNA in saliva using 18S rRNA primers, cox3, and varATS

Overall, the PCR assay using standard 18S rRNA primers detected Pf DNA in 62\% [95\% CI 49-73] of the stored saliva DNA samples, whereas 77\% [95\% CI 64-86] and $68 \%$ [95\% CI 56-79] of the samples were positive with assays using cox3 and varATS primers, respectively (Table 1). Although the differences were not significant based on $95 \% \mathrm{CI}$, the cox3 primers detected more submicroscopic infections compared to the $18 \mathrm{~S}$ rRNA and $\operatorname{varATS}$ (47\% vs. 21 and 26\%, respectively) and had the highest efficiency for malaria detection (Table 2). Interestingly, the ultra-sensitive primers detected $P f$ in more stored saliva DNA samples than were originally detected by TFM $(41 / 60=68 \%)$ and thus were more efficient (Table 2). When stratified by number of parasites in the blood, the cox3 assay detected over $90 \%$ of infections using saliva DNA when individuals had > 1000 parasites/ $\mu \mathrm{l}$ in their peripheral blood (Table 1). For individuals with $>10,000$ parasites $/ \mu \mathrm{l}$ in peripheral blood, both cox3 and varATS assays successfully detected $100 \%$ of the infections, but the sensitivity was reduced at submicroscopic parasitemia levels. US control samples were negative for all primer sets (Additional file 1: Table S1).

\section{Advantages and disadvantages of each assay}

Cox3 PCR consistently showed the brightest and sharpest bands on the gel, whereas the 18S rRNA PCR often produced smeared and non-specific bands with a different size from the expected size (Fig. 1). Interpretation of the gel was also difficult for varATS PCR, as bands were constantly faint and resulted in over $10 \%$ of "unclear" samples (Additional file 1: Table S1). The ultra-sensitive primers-based PCR had another advantage over traditional PCR with much shorter turnaround times than 18S rRNA, $\sim 3.5$ and $\sim 3$ h for cox3 and varATS, respectively, compared to $\sim 7 \mathrm{~h}$ for $18 \mathrm{~S}$ rRNA (Table 3 ).

Table 1 Percentage of saliva samples that tested positive for $P$. falciparum by parasitemia level ( $n=60$ samples)

\begin{tabular}{lllll}
\hline & \multicolumn{5}{c}{$\begin{array}{l}\text { Number positive/number tested } \\
\text { (\% positive) }\end{array}$} \\
\cline { 3 - 5 } Parasites/ $\mu \mathrm{l}$ & $n$ & 18S rRNA & cox3 & varATS \\
\hline Submicroscopic & $19^{*}$ & $4 / 19(21)$ & $9 / 19(47)$ & $5 / 19(26)$ \\
$<1000$ & 6 & $3 / 6(50)$ & $3 / 6(50)$ & $4 / 6(67)$ \\
$>1000$ & 35 & $30 / 35(86)$ & $34 / 35(97)$ & $29 / 35(83)$ \\
All samples & 60 & $62[49-73]$ & $77[64-86]$ & $68[56-79]$ \\
& & $(37 / 60)$ & $(46 / 60)$ & $(41 / 60)$ \\
\hline
\end{tabular}

All samples: data in square brackets show $95 \% \mathrm{Cl}$ calculated using modified Wald method

All samples: data in parentheses show the number of samples that tested positive/total

*Peripheral blood samples from these individuals were PCR positive for malaria 
Table 2 Comparison of the efficiency of thick-film microscopy and PCR

\begin{tabular}{|c|c|c|c|c|c|}
\hline & & \multicolumn{4}{|c|}{ Reference technique } \\
\hline & & $\begin{array}{l}\text { Microscopy } \\
\text { blood (2015) }\end{array}$ & $\begin{array}{l}\text { 18S rRNA PCR } \\
\text { saliva }\end{array}$ & $\begin{array}{l}\text { cox3 PCR } \\
\text { saliva }\end{array}$ & $\begin{array}{l}\text { varATS PCR } \\
\text { saliva }\end{array}$ \\
\hline \multirow[t]{4}{*}{ Experimental technique* } & Microscopy blood (2015) & 1.00 & & & \\
\hline & 185 rRNA PCR saliva & 0.9 & 1.00 & & \\
\hline & cox3 PCR saliva & 1.12 & 1.24 & 1.00 & \\
\hline & varATS PCR saliva & 1.00 & 1.11 & 0.89 & 1.00 \\
\hline
\end{tabular}

*Values greater than 1 indicate higher efficiency than the reference technique. Values less than 1 indicate lower efficiency than reference technique

\section{Discussion}

Non-invasive and sensitive tests for malaria have many applications. This study compared the use of three PCR-based assays to detect $P f$ DNA in saliva. Saliva samples have multiple advantages over blood samples, e.g., no pain for patients, minimal training required for healthcare workers, reduced transmission of blood-borne pathogens, and contaminated sharp wastes. The WHO reported that $37.6 \%$ of hepatitis B, $39 \%$ of hepatitis C, and $4.4 \%$ of HIV/ AIDS prevalence in health workers worldwide are due to needle-stick injury [12]. Saliva tests have been shown to be convenient and safe for cancer, HIV, HCV, HPV, and recently in the field of malaria by detecting HRP-2, lactate dehydrogenase, and $P f$ DNA [6, 13-18].

In the current study, two sets of primers were evaluated, namely primers to the $P$. falciparum genes for cox 3 and varATS, which were first described in 2015. Following its initial report, the cox3 PCR has been used in epidemiological studies $[19,20]$. Since the assay is a nested PCR, cox3 PCR has the benefit of identifying the presence or absence of Plasmodium species in the blood after a single round of PCR amplification. The mitochondrial genome is highly conserved in Plasmodium species [21]. Plasmodium detection using another mitochondrial gene, cytochrome b gene $(c y t b)$, in saliva and urine has been reported in symptomatic patients [6]. However, a more recent study demonstrated that $c y t b$-based PCR has lower sensitivity than cox3-based assays [10].

In a resource- and personnel-limited setting, clear and easy interpretation of results is extremely important and the presence of a single distinct band in gel electrophoresis-based assays help assure accurate diagnosis. The traditional $18 \mathrm{~S}$ rRNA gene-based PCR frequently amplified non-specific bands (Fig. 1), a phenomenon also been reported by others [10, 22]. The extra bands could possibly be due to cross reactivity between human and parasite small subunit rRNA [10]. In contrast, cox3 primers target a gene specific to Plasmodium, thereby eliminating the risk of non-specific amplification of human DNA. VarATS PCR uses a single amplification and produces a small-sized product, making it difficult for researchers to be confident in distinguishing between the true product and non-specific bands on the gel. On the other hand, varATS primers have the advantage of being used in a single-step PCR, thereby significantly reducing the turnaround time and workload required for $\mathrm{nPCR}$.

The process of how parasite DNA enters the human salivary glands and circulates in the saliva remains unclear. Further investigation is also required to determine whether $P f$ DNA in the saliva is present only during an active $P f$ infection or if it persists after parasites are

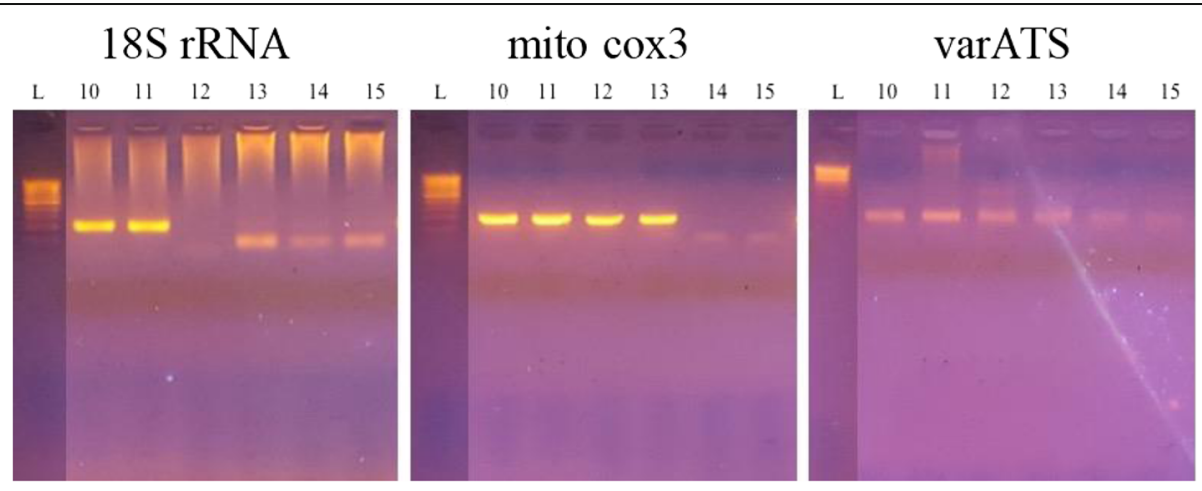

Fig. 1 Representative photographs of gel electrophoresis for 18S rRNA, cox3, and varATS primers using six saliva DNA samples (sample nos. 10-15). Sample nos. 10 and 11 were positive with $18 \mathrm{~S}$ rRNA, since distinct bands of the correct size were visible; sample nos. 10 through 13 were positive with cox3; and sample nos. 10 and 11 were positive with varATS primers, but sample nos. 12-15 were difficult to score. The gel pictures show brighter and more distinct bands for cox3 than 18s rRNA and varATS 
Table 3 Comparison of turnaround time for PCR and gel electrophoresis

\begin{tabular}{llll}
\hline & 18S rRNA & cox3 & varATS \\
\hline Nest 1 & $2 \mathrm{~h} 40 \mathrm{~min}$ & $1 \mathrm{~h} 25 \mathrm{~min}$ & $2 \mathrm{~h} 8 \mathrm{~min}$ \\
Nest 2 & $3 \mathrm{~h} 15 \mathrm{~min}$ & $59 \mathrm{~min}$ & $\mathrm{n} / \mathrm{a}$ \\
Gel & $45 \mathrm{~min}$ & $45 \mathrm{~min}$ & $45 \mathrm{~min}$ \\
Total & $\sim 7 \mathrm{~h}$ & $\sim 3.5 \mathrm{~h}$ & $\sim 3 \mathrm{~h}$ \\
\hline
\end{tabular}

n/a not applicable

cleared from the blood. An inherent problem with rapid diagnostic test based on detection of parasite histidine-rich protein-two (HRP-2) is the persistence of the antigen in the peripheral blood after parasite clearance [23-25].

The project has several limitations. The DNA samples were collected in 2015 and DNA was isolated and stored at $-20{ }^{\circ} \mathrm{C}$ until re-evaluated in 2017 . The saliva samples were collected in 2015 and DNA degradation was likely to have occurred, as the detection of positive saliva samples was higher in the original study than that when archival saliva DNA was used in 2017 with the 18S rRNA primers. DNA degradation in stored samples is not unexpected, as power outages frequently occur in Cameroon. Whether DNA degradation took place is not clear, but it is likely that ultra-sensitive primers would perform even better using fresh saliva samples.

In future studies, a larger number of fresh saliva and blood should be collected and tested with 18S rRNA, $\operatorname{cox} 3$, and varATS primers to establish the true sensitivity of each PCR-based approach. In addition, future studies are needed to determine if other species of malaria (e.g., $P$. vivax, $P$. malariae, $P$. ovale) can also be diagnosed using saliva and if the amount of Plasmodial DNA in saliva reflects the level of parasitemia in the peripheral blood.

\section{Conclusions}

The present study found the PCR assay based on detection of the mitochondrial cox3 gene to be better than the traditional 18s rRNA assay for detecting Pf DNA in stored DNA samples extracted. In addition, PCR using cox3 primers provided bright and distinct band following gel electrophoresis and the assay could be completed in $\sim 3.5 \mathrm{~h}$. The proposed combination of saliva and PCR using cox 3 primers may provide a new tool for use in diagnosis, epidemiological studies, and monitoring interventions for malaria control.

\section{Additional file}

Additional file 1: Table S1. Raw data are provided in the Table. The results have been sorted by parasitemia that was determined by thickfilm microscopy. Shaded blocks indicate where a difference between the three PCR assays evaluated was seen. (DOCX $26 \mathrm{~kb}$ )

\section{Abbreviations}

18S rRNA: 185 small subunit ribosomal RNA; AIDS: Acquired Immune Deficiency Syndrome; bp: Base pair; cox3: Mitochondrial cytochrome c oxidase III; Cytb: Cytochrome b gene; HIV: Human immunodeficiency virus; HPV: Human papillomavirus; HRP-2: Histidine-rich protein 2; LAMP: Loopmediated isothermal amplification; nPCR: Nested polymerase chain reaction; Pf: Plasmodium falciparum or P. falciparum; qPCR: Qualitative PCR; GRTPCR: Quantitative reverse-transcription PCR; TFM: Thick-film microscopy; varATS: var gene acidic terminal sequence; WHO: World Health Organization

\section{Acknowledgements}

We thank the researchers and the laboratory staff at the Biotechnology Centre, University of Yaoundé I, Cameroon, for collecting, processing, and archiving the samples. Our sincere appreciation is sent to all the participants in the study, as this study could not have been carried out without their participation. The OMNIgene ${ }^{\oplus} \mathrm{ORAL}(\mathrm{OM}-501)$ kits were kindly donated by DNA Genotek, Ottawa, Canada.

\section{Funding}

This research was supported by grants T37MD008636 (Minority Health and Health Disparities International Research Training Program, NIMHD), D43TW009074 (Global Infectious Diseases, FIC), P30GM114737 (Centers of Biomedical Research Excellence, NIGMS, NIH), and 5R21AI 105286-02 (NIAID, $\mathrm{NIH}$.

Availability of data and materials

Comparative data for the three PCR assays are provided in Additional file 1: Table S1.

\section{Authors' contributions}

LEF and YML conceived the project and designed the experiments. RC provided ideas on the cox3 primers. STY and KM designed and carried out the original project in 2015 and collected samples with BO and LEF. JA, BT, $B O, C N, L E F$, and YML carried out the experiments. JA, YML, and DWT analyzed the data. RFGL supervised the collection of the samples. YML, JA, $\mathrm{RC}, \mathrm{VRN}$, and DWT wrote the manuscript. All authors reviewed and approved the manuscript.

\section{Ethics approval and consent to participate}

Blood and saliva samples used were deidentified, archival samples collected in 2015. The current study was exempt from human subject research by the Committee on Human Studies, University of Hawaii at Manoa (Protocol Number: 2017-00395).

Competing interests

The authors declare that they have no competing interests.

\section{Publisher's Note}

Springer Nature remains neutral with regard to jurisdictional claims in published maps and institutional affiliations.

\section{Author details}

${ }^{1}$ Department of Tropical Medicine, Medical Microbiology and Pharmacology, John A. Burns School of Medicine, University of Hawaii at Manoa, Honolulu, HI 96813, USA. The Biotechnology Center, University of Yaoundé I, Yaoundé, Cameroon. ${ }^{3}$ The Faculty of Health Sciences, University of Buea, Buea, Cameroon. ${ }^{4}$ Leading Program, Graduate School of Biomedical Sciences, Nagasaki University, Nagasaki, Japan. ${ }^{5}$ Malaria Unit, Department of Pathology, Institute of Tropical Medicine (NEKKEN), Nagasaki University, Nagasaki, Japan. ${ }^{6}$ Present Address: Cancer Early Detection Advanced Research Center, Knight Cancer Institute, Oregon Health and Science University, Portland, USA.

Received: 5 April 2018 Accepted: 24 May 2018

Published online: 22 June 2018

References

1. Wongsrichanalai C, Barcus MJ, Muth S, Sutamihardja A, Wernsdorfer WH. A review of malaria diagnostic tools: microscopy and rapid diagnostic test (RDT). Am J Trop Med Hyg. 2007;77(6 Suppl):119-27. 
2. Karl S, Gurarie D, Zimmerman PA, King CH, St Pierre TG, Davis TM. A submicroscopic gametocyte reservoir can sustain malaria transmission. PLoS One. 2011;6(6):e20805.

3. Britton S, Cheng Q, McCarthy JS. Novel molecular diagnostic tools for malaria elimination: a review of options from the point of view of high-throughput and applicability in resource limited settings. Malar J. 2016;15:88.

4. Hofmann N, Mwingira F, Shekalaghe S, Robinson LJ, Mueller I, Felger I. Ultrasensitive detection of Plasmodium falciparum by amplification of multi-copy subtelomeric targets. PLoS Med. 2015;12(3):e1001788.

5. Haylamicheal ID, Desalegne SA. A review of legal framework applicable for the management of healthcare waste and current management practices in Ethiopia. Waste Manag Res. 2012;30(6):607-18.

6. Putaporntip C, Buppan P, Jongwutiwes S. Improved performance with saliva and urine as alternative DNA sources for malaria diagnosis by mitochondrial DNA-based PCR assays. Clin Microbiol Infect. 2011;17(10):1484-91.

7. Nwakanma DC, Gomez-Escobar N, Walther M, Crozier S, Dubovsky F, Malkin E, Locke E, Conway DJ. Quantitative detection of Plasmodium falciparum DNA in saliva, blood, and urine. J Infect Dis. 2009;199(11):1567-74.

8. Mfuh KO, Tassi Yunga S, Esemu LF, Bekindaka ON, Yonga J, Djontu JC, Mbakop CD, Taylor DW, Nerurkar VR, Leke RGF. Detection of Plasmodium falciparum DNA in saliva samples stored at room temperature: potential for a non-invasive saliva-based diagnostic test for malaria. Malar J. 2017;16(1):434.

9. Snounou G, Viriyakosol S, Jarra W, Thaithong S, Brown KN. Identification of the four human malaria parasite species in field samples by the polymerase chain reaction and detection of a high prevalence of mixed infections. Mol Biochem Parasitol. 1993;58(2):283-92.

10. Isozumi R, Fukui M, Kaneko A, Chan CW, Kawamoto F, Kimura M. Improved detection of malaria cases in island settings of Vanuatu and Kenya by PCR that targets the Plasmodium mitochondrial cytochrome c oxidase III (cox3) gene. Parasitol Int. 2015;64(3):304-8.

11. Cunha MG, Medina TS, Oliveira SG, Marinho AN, Povoa MM, Ribeiro-dosSantos AK. Development of a polymerase chain reaction (PCR) method based on amplification of mitochondrial DNA to detect Plasmodium falciparum and Plasmodium vivax. Acta Trop. 2009;111(1):35-8.

12. Organization WH: World health report 2002. 2002.

13. Zachary D, Mwenge L, Muyoyeta M, Shanaube K, Schaap A, Bond V, Kosloff B, de Haas P, Ayles H. Field comparison of OraQuick ADVANCE rapid HIV-1/2 antibody test and two blood-based rapid HIV antibody tests in Zambia. BMC Infect Dis. 2012;12:183.

14. SahebJamee M, Boorghani M, Ghaffari SR, AtarbashiMoghadam F, Keyhani A. Human papillomavirus in saliva of patients with oral squamous cell carcinoma. Med Oral Patol Oral Cir Bucal. 2009;14(10): e525-8.

15. Wilson NO, Adjei AA, Anderson W, Baidoo S, Stiles JK. Detection of Plasmodium falciparum histidine-rich protein II in saliva of malaria patients. Am J Trop Med Hyg. 2008;78(5):733-5

16. Gbotosho GO, Happi CT, Folarin O, Keyamo O, Sowunmi A, Oduola AM. Rapid detection of lactate dehydrogenase and genotyping of Plasmodium falciparum in saliva of children with acute uncomplicated malaria. Am J Trop Med Hyg. 2010;83(3):496-501.

17. Buppan P, Putaporntip C, Pattanawong U, Seethamchai S, Jongwutiwes S. Comparative detection of Plasmodium vivax and Plasmodium falciparum DNA in saliva and urine samples from symptomatic malaria patients in a low endemic area. Malar J. 2010;9:72.

18. Lee SR, Kardos KW, Schiff E, Berne CA, Mounzer K, Banks AT, Tatum HA, Friel TJ, Demicco MP, Lee WM, et al. Evaluation of a new, rapid test for detecting HCV infection, suitable for use with blood or oral fluid. J Virol Methods. 2011;172(1-2):27-31

19. Chan CW, lata H, Yaviong J, Kalkoa M, Yamar S, Taleo G, Isozumi R, Fukui M, Aoyama F, Pomer A, et al. Surveillance for malaria outbreak on malariaeliminating islands in Tafea Province, Vanuatu after tropical cyclone Pam in 2015. Epidemiol Infect. 2017;145(1):41-5.

20. Idris ZM, Chan CW, Kongere J, Gitaka J, Logedi J, Omar A, Obonyo C, Machini BK, Isozumi R, Teramoto I, et al. High and heterogeneous prevalence of asymptomatic and sub-microscopic malaria infections on islands in Lake Victoria, Kenya. Sci Rep. 2016;6:36958.

21. Hikosaka K, Watanabe Y, Kobayashi F, Waki S, Kita K, Tanabe K. Highly conserved gene arrangement of the mitochondrial genomes of 23 Plasmodium species. Parasitol Int. 2011;60(2):175-80.

22. Kimura M, Kaneko O, Liu Q, Zhou M, Kawamoto D, Wataya Y, Otani S, Yamaguchi Y, Tanabe K. Identification of the four species of human malaria parasites by nested PCR that targets variant sequences in the small subunit rRNA gene. Parasitol Int. 1997;46(2):91-5.

23. Grandesso F, Nabasumba C, Nyehangane D, Page AL, Bastard M, De Smet $M$, Boum Y, Etard JF. Performance and time to become negative after treatment of three malaria rapid diagnostic tests in low and high malaria transmission settings. Malar J. 2016;15(1):496.

24. Kilauzi AL, Mulumba JG, Magafu MG, Matchaba-Hove R, Tapera R, Magafu NS, Tamfum JJ. SD Bioline malaria antigen Pf (HRP-2/pLHD) for assessing efficacy of artemisinin combination therapy against Plasmodium falciparum in pediatric patients in the Democratic Republic of the Congo. Pan Afr Med J. 2015;22:304

25. Kattenberg JH, Tahita CM, Versteeg IA, Tinto H, Traore-Coulibaly M, Schallig $H D$, Mens PF. Antigen persistence of rapid diagnostic tests in pregnant women in Nanoro, Burkina Faso, and the implications for the diagnosis of malaria in pregnancy. Tropical Med Int Health. 2012;17(5):550-7.

\section{Ready to submit your research? Choose BMC and benefit from:}

- fast, convenient online submission

- thorough peer review by experienced researchers in your field

- rapid publication on acceptance

- support for research data, including large and complex data types

- gold Open Access which fosters wider collaboration and increased citations

- maximum visibility for your research: over $100 \mathrm{M}$ website views per year

At BMC, research is always in progress.

Learn more biomedcentral.com/submissions 